\title{
Perception of Physical Education Teachers on Adaptive Physical Education in Inclusive School
}

\author{
Prakosha, D. ${ }^{1}$, Kristiyanto, A. ${ }^{2}$, Gunarhadi ${ }^{3}$, Salim, A. ${ }^{4}$, Sunardi ${ }^{5}$ \\ Special Education Magister Program, Sebelas Maret University
}

Corresponding email: donniipp@gmail.com

\begin{abstract}
Physical education is an important thing to teach in an effort to maintain health. In the term of special education, adaptive physical education is very necessary in teaching physical education for students with special needs. The main purpose of this study is to determine the perceptions of teachers, especially special teachers, on adaptive physical education in inclusive schools. This study used survey approach involving 15 teachers in Surakarta. Data was collected using questionnaires using 4 Likert scale. The results showed that teachers' perception on the purpose of adaptive physical education was high for $70 \%$. Meanwhile, teachers' perception on the implementation of physical adaptive education was high for $62 \%$. However, teachers' perception on the adaptive physical education materials was moderate for $56 \%$. Also for the assessment in adaptive physical education, teachers' perception was moderate for 58\%. In terms of the physical adaptive education tools, teachers' perception was high for $81 \%$.
\end{abstract}

Keywords: Perception of teachers, adaptive physical education.

DOI: $10.20961 /$ ijpte.v2i1.17042 


\section{INTRODUCTION}

Children with special needs are children having different ability in the term of their mental, sensory, physical and neuromascular ability, social and emotional behavior, and communication skill (Mangunsong, 2009: 4). Children with special needs are also defined as children having different ability compared to other regular children (Efendi, 2006: 2). Each disability has its own characteristics. Since they have different characteristics, intervention and modification are needed to adjust the characteristics of each disability.

Students with disabilities have the same right to learn in school as the general school population. There should be no discrimination in the field of education, including children with special needs. An increasing numbers of students with special needs are enrolling into educational institution. Tsai et.al (2013) state that all people have equal opportunity in education, regardless of their social class, ethnicity, background, or physical disabilities. Students with disabilities have rights to expect the same education as other students without considering their disability.

One educational institution that gives opportunity for students with disability to learn together with regular students in one place is inclusive school. Inclusive school is a school that provides educational services to accommodate all students by considering their learning needs, yet omitting their physical and mental condition to learn together in a regular class (Schmidt \& Venet, 2012; SaponShevin, 2007; UNESCO, 2000). In inclusive school, all students are provided the same subjects, as well as physical education.

Physical education is important to maintain the students' health and body condition. However, it should be adjusted with students' condition and ability remembering that there are students with disability in inclusive school. Rejeki (2016) states that sport learning should be adjusted with the children's need and specificity levels so that the disabled children's health needs will be fulfilled, either physically or mentally. Thus, the regular physical education should be adjusted with disabled students' condition by altering to adapted physical education. Adaptive physical education is a physical education program that is adapted or modified based on the needs of the students' condition (Ainin, 2011).

The success of this learning goal is influenced by some factors. One important and main factor is teachers. Teachers become an important factor to create good learning quality. However, based on statistical report, 95\% of adaptive physical education teachers have non-physical or non-sport educational background. Meanwhile, to give optimal educational services, especially in the terms of adaptive physical education, teachers should possess knowledge and skill to administer adaptive physical education. This condition is important to be noticed. Thus, teachers' perception on adaptive physical education needs to be observed.

\section{RESEARCH METHOD}

In this research, the researcher used descriptive quantitative method. The purpose of this research method is to illustrate how the state of accessibility in inclusive 
schools for children with special needs. Researchers only develop concepts and collect facts but do not perform hypothesis testing. There is an opinion from Gorman \& Clayton that this research method is to report the meaning of event from what is observed by researchers (Santana, 2007: 28). At the stage of the report, contains observations of events and interactions observed directly by researchers from the scene (Santana, 2007: 28).

This study used survey approach involving 15 sport teachers in Surakarta residence. Data was collected by using questionnaires using Likert scale. The answer options given were strongly agree (SA), agree (A), disagree (D), and strongly disagree (SD). There were 20 items of questions calculated by percentage. Those 20 items were divided into 5 parts, namely (1) purpose of adaptive physical education, (2) the implementation of adaptive physical education, (3) adaptive physical education materials, (4) assessment in adaptive physical education, and (5) physical adaptive education tools. The overall score were counted into percentage and classified into five levels.

Table 1. Level Classification

\begin{tabular}{cl}
\hline Percentage & Level \\
\hline$\leq 1 \%-\leq 20 \%$ & Very Low \\
\hline$\leq 21 \%-\leq 40 \%$ & Low \\
\hline$\leq 41 \%-\leq 60 \%$ & Moderate \\
\hline$\leq 61 \%-80 \%$ & High \\
\hline$\leq 81 \%-100 \%$ & Very High \\
\hline
\end{tabular}

\section{RESULT AND DISCUSSION}

In this chapter, the result of answered questionnaire are showed and elaborated. The result and elaboration are shown as follows.

\section{Purpose of adaptive physical education}

The highest score in this part was 240 points. The score was divided into 4 items, namely 60 points for each item. The first, second, and fourth statements were favorable items with score in detail were $S A=4$ points, $A=3$ points, $D=2$ points, and $\mathrm{SD}=1$ point. The third statement was an unfavorable item with score in detail were $\mathrm{SA}=1$ point, $\mathrm{A}=2$ points, $\mathrm{D}=3$ points, and $\mathrm{SD}=4$ points. The result can be seen in the form of table as follows.

Table 2. Purpose of adaptive physical education

\begin{tabular}{|c|c|c|c|c|c|c|c|}
\hline No. & Statement & SA & A & D & SD & Score & Percentage \\
\hline 1 & Statement 1 & 2 & 10 & 3 & 0 & 44 & $73 \%$ \\
\hline 2 & Statement 2 & 5 & 10 & & & 50 & $83 \%$ \\
\hline 3 & Statement 3 & 6 & 8 & 1 & & 25 & $42 \%$ \\
\hline 4 & Statement 4 & 4 & 11 & & & 49 & $82 \%$ \\
\hline \multicolumn{6}{|c|}{$\begin{array}{c}\text { Total Score } \\
\end{array}$} & 168 & $70 \%$ \\
\hline
\end{tabular}

From the result above, it can be seen that teachers' perception on the purpose of adaptive physical education was high for $70 \%$. The first statement stated that the main purpose of physical adaptive education is to increase students' health. The 
second statement had the highest percentage (83\%) in this part and stated that adaptive physical education also aims to improve students' confidence in inclusive school. The lowest percentage (42\%) was on the third statement that adaptive physical education only for students with special needs. The last statement of this part is that adaptive physical education can be used to improve students' socialization skill.

2. The implementation of physical adaptive education

The highest score in this part was 300 points. The score was divided into 5 items, namely 60 points for each item. The first and second statements were favorable items with score in detail were $S A=4$ points, $A=3$ points, $D=2$ points, and $S D=1$ point. The third, fourth, and fifth statements were unfavorable items with score in detail were $S A=1$ point, $A=2$ points, $D=3$ points, and $S D=4$ points. The result can be seen in the form of table as follows.

Table 2. The implementation of physical adaptive education

\begin{tabular}{cccccccc}
\hline No. & Statement & SA & A & D & SD & Score & Percentage \\
\hline 1 & Statement 1 & & 9 & 6 & 39 & $65 \%$ \\
\hline 2 & Statement 2 & 6 & 9 & & 51 & $85 \%$ \\
\hline 3 & Statement 3 & 5 & 10 & & 33 & $42 \%$ \\
\hline 4 & Statement 4 & 3 & 1 & 11 & 47 & $63 \%$ \\
\hline 5 & Statement 5 & 3 & 6 & 6 & 42 & $55 \%$ \\
\hline & Total Score & & $\mathbf{2 1 8}$ & $\mathbf{6 2 \%}$ \\
\hline
\end{tabular}

From the result above, it can be seen that teachers' perception on the implementation of physical adaptive education was high for $62 \%$. The first statement stated that adaptive physical education is implemented to prevent more severe damage for students with disability. The second statement had the highest percentage (85\%) in this part and stated that adaptive physical education is implemented by looking at students' condition. The lowest percentage (42\%) was on the third statement that teachers have an authority to adjust adaptive physical education without any regulation. The fourth statement was that students with disability have no right to be model in adaptive physical education. The last statement of this part is that to implement adaptive physical education, teachers do not need competing normal students and students with special needs.

3. Adaptive physical education materials

The highest score in this part was 240 points. The score was divided into 4 items, namely 60 points for each item. All statements in this part were favorable items with score in detail were $S A=4$ points, $A=3$ points, $D=2$ points, and $S D=1$ point. The result can be seen in the form of table as follows.

Table 3. Adaptive physical education materials

\begin{tabular}{cccccccc}
\hline No. & Statement & SA & A & D & SD & Score & Percentage \\
\hline 1 & Statement 1 & & 10 & 1 & 4 & 42 & $65 \%$ \\
\hline 2 & Statement 2 & 4 & 11 & & & 34 & $57 \%$ \\
\hline 3 & Statement 3 & 1 & 12 & 2 & & 30 & $45 \%$ \\
\hline 4 & Statement 4 & 6 & 9 & & & 40 & $57 \%$ \\
\hline
\end{tabular}




\section{Total Score $134 \quad 56 \%$}

From the result above, it can be seen that teachers' perception on the adaptive physical education materials was moderate for $56 \%$. The first statement stated that sport game is the main materials taught in adaptive physical education. The second statement stated that all kinds of sport can become materials in adaptive physical education. The lowest percentage (45\%) was on the third statement that material in adaptive sports education is the same with material in regular physical education for regular students. The last statement of this part is that in group games, students with special needs should be grouped with the strongest/superior students.

\section{Assessment in adaptive physical education}

The highest score in this part was 240 points. The score was divided into 4 items, namely 60 points for each item. The first and second statements were favorable items with score in detail were $\mathrm{SA}=4$ points, $\mathrm{A}=3$ points, $\mathrm{D}=2$ points, and $\mathrm{SD}=1$ point. The third and fourth statements were unfavorable items with score in detail were $\mathrm{SA}=1$ point, $\mathrm{A}=2$ points, $\mathrm{D}=3$ points, and $\mathrm{SD}=4$ points. The result can be seen in the form of table as follows.

Table 4. Assessment in adaptive physical education

\begin{tabular}{|c|c|c|c|c|c|c|c|}
\hline No. & Statement & SA & A & D & SD & Score & Percentage \\
\hline 1 & Statement 1 & & 10 & 1 & 4 & 36 & $60 \%$ \\
\hline 2 & Statement 2 & 4 & 11 & & & 49 & $82 \%$ \\
\hline 3 & Statement 3 & 1 & 12 & 2 & & 31 & $52 \%$ \\
\hline 4 & Statement 4 & 6 & 9 & & & 24 & $40 \%$ \\
\hline \multicolumn{6}{|c|}{ Total Score } & 140 & $58 \%$ \\
\hline
\end{tabular}

From the result above, it can be seen that teachers' perception on the assessment in adaptive physical education was moderate for 58\%. The first statement stated that the assessment criteria in adaptive physical education are different from regular physical education. The second statement had the highest percentage (82\%) in this part and stated that the standard score in adapted physical education is different from regular physical education. The third statement stated that in adaptive physical education, teachers need to assess students' skill/achievement only. The lowest percentage (40\%) was on fourth statement that the difference between the assessment for students with disability and regular students should be explained at the beginning of the lesson.

\section{Physical adaptive education tools}

The highest score in this part was 180 points. The score was divided into 3 items, namely 60 points for each item. All statements in this part were favorable items with score in detail were $\mathrm{SA}=4$ points, $\mathrm{A}=3$ points, $\mathrm{D}=2$ points, and $\mathrm{SD}=1$ point. The result can be seen in the form of table as follows.

Table 5. Physical adaptive education tools

\begin{tabular}{cccccccc}
\hline No. & Statement & SA & A & D & SD & Score & Percentage \\
\hline 1 & Statement 1 & 2 & 13 & & & 47 & $78 \%$ \\
\hline
\end{tabular}




\begin{tabular}{cccccc}
\hline 2 & Statement 2 & 4 & 11 & 49 & $82 \%$ \\
\hline 3 & Statement 3 & 4 & 11 & 49 & $82 \%$ \\
\hline \multicolumn{7}{c}{ Total Score } & $\mathbf{1 4 5}$ & $\mathbf{8 1 \%}$ \\
\hline
\end{tabular}

From the result above, it can be seen that teachers' perception on the physical adaptive education tools was high for $81 \%$. The first statement had the lowest percentage (78\%) in this part and stated that all physical education teachers should master adaptive physical education. The second statement stated that workshop/training about adaptive physical education should be held for physical education teachers. The last statement was that guiding books for adaptive physical education should be made.

\section{CONCLUSIONS}

The observation result showed that teachers' perception on the purpose of adaptive physical education was high for $70 \%$. Meanwhile, teachers' perception on the implementation of physical adaptive education was high for $62 \%$. However, teachers' perception on the adaptive physical education materials was moderate for $56 \%$. Also for the assessment in adaptive physical education, teachers' perception was moderate for $58 \%$. In terms of the physical adaptive education tools, teachers' perception was high for $81 \%$.

Based on the analysis result, it can be concluded that teachers' perception, especially physical education teachers, on adaptive physical education is high. However, in some parts, they still need more explanation so that they can improve their knowledge in term of adapted physical education.

\section{REFERENCES}

Ainin, Ima Kurrotun. 2011. Strategi Pembelajaran Pendidikan Jasmani Adaptif. JASSI Anakku. (10) 149-164.

Mangunsong, Frieda. 2009. Psikologi dan pendidikan anak berkebutuhan khusus jilid 1. Jakarta: LPSP3 UI.

Santana, Septiawan. 2007. Menulis Ilmiah: Metode Penelitian Kualitatif. Jakarta: Yayasan Obor Indonesia.

Schmidt, S \& Venet, M. 2012. Principals Facing Inclusive Schooling or Integration. Canadian Journal of Education, 35 (1), 217-238.

Sapon-Shevin, Mara. 2007. Widening the Circle the Power of Inclusive Classrooms. Boston: Bacon Press.

Tsai, Li-Ting, et.al. 2013. Effects of Visual Rehabilitation on a Child with Severe Visual Impairment. The American Journal of Occupational Therapy. (67) 437-447.

UNESCO. 2000. The Salamanca Statement and Framework for Action on Special Needs Education. Paris: Author. 